\title{
Training Elementary Students' Collaborative and Entrepreneurship Skills Using Science Student Worksheet Based on Project Learning
}

\author{
${ }^{1}$ Muhammadiyah University of Surabaya, Surabaya 60113, Indonesia \\ ${ }^{2}$ Physics Education, Universitas Negeri Surabaya, Surabaya 60294, Indonesia \\ ${ }^{3}$ Science Education, Universitas Negeri Surabaya, Surabaya 60294, Indonesia \\ *Corresponding author. Email: nailaishma@gmail.com
}

Ishmatun Naila $^{1 *}$, Budi Jatmiko ${ }^{2}$, Elok Sudibyo ${ }^{3}$

\begin{abstract}
This study aims to practice the collaboration and entrepreneurship skills of elementary school students. This research is a type of development of the 4D model, which was adapted into the 4P model, which is defining, planning, developing, and disseminating. This research conducted 30 students of fifth grade in Muhammadiyah 4 Surabaya Elementary School. Data analysis methods used were t-test, N-Gain analysis, and observation to find out if there was an improvement after learning. The results of the analysis using the t-test showed a significant increase in collaboration skills in pre and post-test, with post-test values better than pretest (negative t). The results of the N-Gain analysis showed the average increase in student scores of collaboration skills in the high category. The observation of entrepreneurship skills showed that it was started to appear in students. The students' collaboration and entrepreneurship skills were successfully trained using the developed worksheet.
\end{abstract}

Keywords: training collaboration, project learning, entrepreneurship, 4D model

\section{INTRODUCTION}

Learning sciences for elementary school students in the 21 st century has been generating with various methods and models of learning that are varied and innovative. Students no longer just sit still and listen to the teacher explain, but instead actively discover something new by only beginning a question/stimulus from the teacher. "Education is not the learning of facts, but the training of the mind to think [1]." It was revealed in Einstein's statement above, education or education is not learning facts, but training by the mind to think. The more students think about finding new knowledge for them, then that is where the educational process takes place.

Permendikbud No. 23 of the assessment standards and the latest assessment guidelines contain improvements in integrating Strengthening Character Education (PPK) in learning. The reinforced characters are mainly five characters, namely: religious, nationalist, independent, cooperation, and integrity. Besides PPK on learning it needs to be integrated, that is literacy (Gerakan Literasi Sekolah/ GLS); 21st-century skills or termed 4C (Creativity and Innovation, Critical Thinking and Problem Solving, Collaboration, and Communication); and HOTS (Higher Order Thinking Skill). 21st-century skills or termed with 4C is what becomes the goal in $\mathrm{K}-13$, not just the transfer of material but the formation of $4 \mathrm{C}$ [2]. On various occasions, some experts have often heard explaining the importance of mastering $4 \mathrm{C}$ as a means of achieving success especially in the 21st Century, a century where the world is developing very quickly and dynamically [3].

Mastering 21st-century skills are essential, 4C is a type of soft skill that in everyday implementation, is far more useful than just the handling of hard skills. One of the 4C skills, namely collaboration, is the philosophy of interaction and personal lifestyle in which individuals are responsible for their actions, including learning and respecting the abilities and contributions of their peers. Evidence of research by Johnson \& Johnson [4]; Hake [5]; Vogiatzaki \& Avouris [6] that such an approach has a positive effect on learning outcomes.

Project-based learning has become the main strategy used by most of the best education systems in the world. Authentic learning that addresses 21 st-century skills is what project-based learning (PjBL) offers [7]. According to research conducted by Frank and Barzilai [8], there is a rapid increase in the use of $\mathrm{PjBL}$ teaching methods in Science classrooms. The benefit for students is that they can actively participate in project-based learning in class, where they are asked to work collaboratively to solve problems, and then discuss and reflect on what they have learned.

The 4.0 industrial revolution that is going on in this world requires humans to continue to change before being changed [9]. Much different from before, the 4.0 industrial revolution has a scale of complexity and wider scope. Various new digital technologies that continue to shift the role of humans in their profession massively, cannot be denied will continue to develop. With the increase in the number of school graduates, unemployment in Indonesia will also increase if school graduates do not have skills in the field of entrepreneurship. 
Entrepreneurship-based learning for 11-year-old students is a good time based on Hassi research [10]. The research findings found that children aged 11-12 years are sufficient periods to develop self-efficiency, non-cognitive skills needed to become entrepreneurs. From the problems above, one of the problems that must be immediately addressed is the ability of students in terms of skills that must be mastered in the 21st century, namely collaboration and entrepreneurship skills. These skills are relevant to be developed so that later students can take an important role or have achievements in their lives as a society, citizens of the country, and citizens of the world. Researchers hope that research can overcome problems in group learning activities / work on assignments in groups so as to improve student collaboration and entrepreneurship skills.

\section{METHOD}

\subsection{The validity of Student Worksheet}

The researcher designed the student worksheet and gave them to experts to evaluate. Three experts assessed them in validation's sheets in the form of value and gave suggestions and criticism. The results of the validation questionnaire and suggestions from the validator are documented. The validator assessed by checking $(\sqrt{ })$ in the appropriate value column. The column contains the assessment scores that have been determined, on each validation sheet there are four categories, namely: (a) not good (value 1), (b) quite good (value 2), (c) good (value 3), and (d) very good (value 4 ).

Analysis of data from the student worksheet validation was obtained through the values on the expert validation questionnaire sheet. This analysis is done by averaging the scores of each component given by the validators. The results of the validation conducted by the validator indicate that the validated student worksheet is valid to train students' collaboration and entrepreneurship skills.

\subsection{Practicality of Student Worksheet}

Observers witnessed the implementation of the student worksheet to improve student's collaboration and entrepreneurship skills. Each observer checks all of the aspects done in observation form. Observation is conducted during learning activities by 2 observers in each class. Assessment form (observation form) is divided into 2 criteria, those are implemented and not implemented. Data analysis technique to analyse the practicality of the worksheet using percentage technique, as seen below [11]: $P=\frac{A}{B} x 100 \%$.

P : Percentage; A : Frequency of student's activity; B : Amount of aspect

The instrument is reliable if it gets a percentage of $\geq 75 \%$. Percentage criteria of practicality learning devices are given below [12]:

$\mathrm{P}=0 \%-24 \%$ Not implemented
$\mathrm{P}=25 \%-49 \%$ Poor implemented

$\mathrm{P}=50 \%$ - 74\% Good implemented

$\mathrm{P}=75 \%-100 \%$ Excellent implemented

\subsection{Effectivity of Student Worksheet}

Data collection methods used to measure collaboration skills in the form of pre-test and post-test with the same questions. The pre-test is given 30 minutes before learning at the first meeting, while post-test is 30 minutes after the third (last) meeting. There are 4 descriptive questions that each student worked on. The questions are arranged based on collaboration skills indicators. Calculation of test results using a scale of 0-3. Significance of improving collaboration skills is obtained from hypothesis testing using t-tests with the condition that the analysed n-gain data should be normally distributed. The formula is:

$t-t e s t=\frac{\frac{d}{s d}}{\sqrt{n}}$

$\mathrm{d}$ : average value of the difference between paired observations; sd : standard deviation of differences between paired observations; and $\mathrm{n}$ : number of samples

To find out the degree of improvement in collaboration skills, an inferential statistical analysis was done through the N-Gain analysis of pre-test and post-test scores. The formula is:

$$
N-\text { gain }=\frac{\text { post test score }- \text { pre test score }}{\text { maximum score }- \text { pre test score }}
$$

Table 1 N-Gain Category

\begin{tabular}{|cc|}
\hline Range of Scores & Category \\
\hline $0,70 \leq \mathrm{g} \leq 1,00$ & High \\
$0,30 \leq \mathrm{g}<0,70$ & Mid \\
$0,00<\mathrm{g}<0,30$ & Low \\
\hline
\end{tabular}

To find out the characteristics of entrepreneurship that appear in students, observations are made when the learning occurs. Observation sheet contains aspects and indicators of entrepreneurship characteristics observed by one observer for each group.

\section{RESULTS AND DISCUSSION}

The Student Worksheet developed consists of 4 parts namely "SW 1" concerning the water cycle, "SW 2" concerning types of organic and inorganic waste along with their impact on the environment, "SW 3" regarding project assignments (waste processing for recycling), and "SW 4" contains about how to use organic waste to compost. This worksheet is adjusted to the Learning Implementation Plan developed.

The process of developing student worksheet requires quite a long time because it needs to do material analysis and adjust indicators in the lesson plan. The results of the analysis are then used as a basis for the development of the worksheet. After being arranged and consulted with the 
supervisor, several revisions were made before submitting it to the validator. The validator provides suggestions and input so that the worksheet can be used for learning in students.

\subsection{The Validity of Student Worksheet}

Validation of student worksheet aims to assess the feasibility of several aspects of teaching materials by experts before being used in learning. Then the worksheet is revised according to the suggestions and input from experts and it is hoped that the improvement can produce a valid student worksheet. Validated aspects of worksheet are construction, technical, and didactic. The results of the student worksheet validation are as follows:

Table 2 The Validity of Student Worksheet

\begin{tabular}{|c|c|c|c|}
\hline \multicolumn{2}{|r|}{ Component / Indicators } & Mode & Category \\
\hline \multicolumn{4}{|c|}{ Construction } \\
\hline 1 & Clarity of formulation of work steps & 4 & Very Valid \\
\hline 2 & Clarity of numbering system & 4 & Very Valid \\
\hline 3 & Accuracy of spatial / layout settings & 4 & Very Valid \\
\hline 4 & Clarity of instructions and direction & 4 & Very Valid \\
\hline 5 & Compatibility of physical worksheet with students & 3 & Valid \\
\hline 6 & Conformity of sentences with the level of thinking and reading ability of students & 4 & Very Valid \\
\hline 7 & Encourage interest in working scientifically & 4 & Very Valid \\
\hline \multicolumn{4}{|c|}{ Technical } \\
\hline 1 & The exactness of grammar & 3 & Valid \\
\hline 2 & Simplicity of sentence structure & 4 & Very Valid \\
\hline 3 & The sentence does not contain a double meaning/ambiguous & 4 & Very Valid \\
\hline 4 & The language used is communicative & 4 & Very Valid \\
\hline 5 & The accuracy of the type and size of the letters & 3 & Valid \\
\hline \multicolumn{4}{|c|}{ Didactic } \\
\hline 1 & The accuracy of material / content & 4 & Very Valid \\
\hline 2 & The essence of materials & 4 & Very Valid \\
\hline 3 & The suitability of the task with the order of material & 4 & Very Valid \\
\hline \multirow[t]{2}{*}{4} & The eligibility as a learning device & 4 & Very Valid \\
\hline & Reliability & 0.91 & \\
\hline
\end{tabular}

Based on Table 2 above, the results of the validation of Student Worksheets by the validator have mode 4 with a very valid category and a reliability of 0.91 which shows a reliable and feasible worksheet. Student worksheet developed based on entrepreneurship-oriented projectbased learning aims to improve students' collaboration and entrepreneurship skills. Before being tested, the worksheets that were developed were validated beforehand by the validator. The validation results are presented in Table II which shows the validation mode score of 4 with a very valid category. To determine the level of trust calculated reliability and the results of 0.91 and included in the category of reliable. Preparation of student worksheet requires quite a long time, because it has to do several steps in the process. First is the analysis of material and the adjustment of indicators in the lesson plan. After getting the results of the analysis compiled, the worksheet that has been arranged then consulted with the supervisor with several revisions and then validated by the validator.

In addition to the results of validation in the form of values, the validator also provides some suggestions and input so that the developed worksheet become better. Suggestions given by the validator is that the worksheet need to be arranged coherently and contain objectives, tools and materials, procedures, results of analysis, quizzes, and conclusions. The worksheet contains several experimental activities that can train students' collaboration and entrepreneurship skills.

\subsection{The Practicality of Student Worksheet}

The practicality of the worksheet is assessed from the results of observations of the implementation of learning in the learning process in class V Muhammadiyah 4 Surabaya Elementary School using an entrepreneurship-oriented project-based student worksheet. The details of the observations of the practicality of the worksheet are shown in Table 3.

Learning activities carried out during four activities in the worksheet. The implementation of this learning is carried out referring to the Learning Implementation Plan that has been developed by integrating project-based learning and entrepreneurship and has three activities, namely introduction, core, and closing. Based on table III, the average percentage obtained for the implementation of class $\mathrm{V}$ learning at Muhammadiyah 4 Surabaya Elementary School at the first to fourth activities were $100 \%$. These results indicate that learning at first to the fourth activity was carried out well. The results of the implementation of learning in class $\mathrm{V}$ are said to be reliable because they have a reliability of $100 \%$ for all activities.

In the core learning activities, students are invited to be actively involved in finding knowledge through several experimental activities in worksheet that students do themselves. Students form heterogeneous groups, and 
together conduct experiments on the environment. The experiments include making a miniature water cycle in nature, conducting experiments related to erosion, decomposing organic and inorganic waste for use as compost, and the main project activity is to recycle waste that is difficult to decompose. The whole experiment was also directed to train students' collaboration and entrepreneurship skills.

In this entrepreneurship-oriented project-based learning teacher facilitates students to work on projects collaboratively so that they will train their ability to contribute, solve problems, work effectively with a diversity of members, manage projects, leadership skills, and confidence. From the discussion above, it is known that the worksheet is reliable and appropriate to be used in learning to train student collaboration and entrepreneurship skills. Table 3 shows that learning with the four worksheets has been carried out well. All implementations and reliability are $100 \%$, all four can be said to be reliable and excellent implemented.

Table 3 The Practicality of Student Worksheet

\begin{tabular}{|c|c|c|c|c|c|c|c|c|}
\hline \multirow[t]{2}{*}{ Activity } & \multicolumn{2}{|c|}{ SW 1} & \multicolumn{2}{|c|}{ SW 2} & \multicolumn{2}{|c|}{ SW 3} & \multicolumn{2}{|c|}{ SW 4} \\
\hline & 01 & $\mathrm{O} 2$ & 01 & $\mathrm{O} 2$ & 01 & $\mathrm{O} 2$ & 01 & $\mathrm{O} 2$ \\
\hline Percentage of implementation & 100 & 100 & 100 & 100 & 100 & 100 & 100 & 100 \\
\hline Average & \multicolumn{2}{|c|}{$100 \%$} & \multicolumn{2}{|c|}{$100 \%$} & \multicolumn{2}{|c|}{$100 \%$} & \multicolumn{2}{|c|}{$100 \%$} \\
\hline Reliability & \multicolumn{2}{|c|}{$100 \%$} & \multicolumn{2}{|c|}{$100 \%$} & \multicolumn{2}{|c|}{$100 \%$} & \multicolumn{2}{|c|}{$100 \%$} \\
\hline
\end{tabular}

SW: Student Worksheet; O: Observer

\subsection{The Effectivity of Student Worksheet}

Analysis of the results of collaboration skills is based on data obtained from the fifth-grade collaboration skills test and analysed using the t-test and N-Gain formula. The t-test was used to calculate the significance of the improvement in collaboration skills, while the N-Gain was to determine the degree of improvement in collaboration skills. Table IV shows that N-Gain all indicators of collaboration skills have a high category with a range between $0.71-0.77$.

Table 4 N-Gain Result

\begin{tabular}{|lllll|}
\hline \multicolumn{1}{c}{ Indicators } & Pre-test & Post-test & N-Gain & Category \\
\hline Contributions & 42.50 & 83.33 & 0.71 & High \\
Working effectively in diversity members & 45.00 & 87.50 & 0.77 & High \\
Contributions & 45.83 & 87.50 & 0.77 & High \\
Project management & 46.67 & 87.50 & 0.77 & High \\
\hline
\end{tabular}

Table 5 Paired t-test result

\begin{tabular}{|c|c|c|c|c|}
\hline & Paired Differences & $\mathbf{t}$ & df & $\mathbf{p}$ \\
\hline & $\begin{array}{l}95 \% \text { Confidence Interval of } \\
\text { the Difference }\end{array}$ & & & \\
\hline & Lower $\quad$ Upper & & & \\
\hline PRE-TEST.B - POST-TEST.B & -46.85008 & -16.464 & 29 & .000 \\
\hline
\end{tabular}

According to Table 5 , the p-value $<0.05$, so it can be seen that there is a significant difference between the pre-test and post-test values, with a negative $t$ value, means that the $\mathrm{H} 1$ region is accepted on the left, where the post-test value is better than the pre-test value.

Observations of entrepreneurship skills in students use the observation table observed by one observer for each small group. Observations were made during three lessons in class V. Observation refers to the observation sheet of entrepreneurship skills that is filled in by the observer. The results of observations in the class $\mathrm{V}$ at the first, second, and third meeting can be seen in Table 6

Table 6 Observation Results of Student Entrepreneurship Skills

\begin{tabular}{|lccc|}
\hline Aspects & $1^{\text {st }}$ Meeting & $2^{\text {nd }}$ Meeting & $3^{\text {rd }}$ Meeting \\
\hline Confidence & 56 & 71 & 89 \\
Results Oriented & 47 & 61 & 84 \\
Leadership & 52 & 70 & 83 \\
Future Oriented & 55 & 68 & 87 \\
\hline
\end{tabular}

The results of observations on entrepreneurship skills in class V show the results that the characteristics of entrepreneurship began to emerge in students, and the average increased at each subsequent meeting. The collaboration skills test consisted of 4 problem descriptions, each of which represented indicators of collaboration skills and learning indicators [13]. The analysis used to test the difference in sample mean is the t-test [14]. But before conducting the t-test, there are several requirements that must be met, namely the group to be tested must be 
normally distributed and homogeneous. In this study, the normality test was carried out using the KolmogorovSmirnov formula to find out whether the samples (pre-test and post-test) in class $\mathrm{V}$ were normally distributed.

The results showed that all samples were normally distributed because of $p>0.05$. Because the requirements have been met then the $t$-test is then performed. Based on paired t-test analysis conducted, it is known that there are differences between pre-test and post-test results before and after learning using entrepreneurship-oriented projectbased learning, with a negative $t$ value which means $\mathrm{H} 1$ is in the left area, where the post-test higher than pre-test. Based on the results of the t-test, it turns out that projectbased learning can significantly enhance student collaboration skills (Table 5).

Data on the significance of (p) improvement of collaboration skills are also by the results of N-Gain calculations [13]. The difference in results before and after learning can be seen in Table IV for the N-Gain of each indicator of collaboration skills. Based on the data in the table, it can be seen that the N-Gain of each indicator of the collaboration skills of fifth-grade students is high categorized. In general, collaboration skills have increased significantly. It is consistent with research conducted by Marx, et al. [15] that project-based science learning can foster collaboration skills. Collaboration is a significant component in project-based science learning because it can provide opportunities for students to share ideas, develop their thoughts, utilize the expertise of others, and experience the value of thinking intelligently.

In order to know the rise of entrepreneurship characteristics in students is done through observation. Observations made by observers to determine the growth of entrepreneurial characteristics are made during the learning process using observation sheets that have been prepared by researchers. Based on observations, the average of the four main aspects of characteristics that researchers want to train in students continue to increase at each meeting in class $\mathrm{V}$. This shows that in students has appear the characteristics of an entrepreneur. This result is in accordance with research conducted by Hassi [10] which states that students at the age of 11-12 years (age of grade V elementary school) are sufficient periods to develop self-efficiency, non-cognitive skills needed to become an entrepreneur.CONCLUSION The results of the preliminary study at the analysis stage revealed that the implementation of character education has not been implemented in a comprehensive manner, the fulfilment of the Environment and Culture Situation of the School of Character Education Implementation has not been fulfilled as a whole and the character of students in general has been categorized as low.

The School Culture-based character education model in Primary Schools was stated to meet the validity criteria, and practicality. Validated based on the results of the validity test by experts and practical because based on the results of the model implementation, it was found that the teacher's response to the implementation of the model for all aspects or components was in the "very good" category. While the results of the implementation of the model for all aspects or components are "fully implemented" or are in the "very good" category. The school culture-based character education model meets the effectiveness criteria. It is declared effective because it gets a positive response from students and can improve the character of students. The school culture-based character education model can be used to develop student character at the elementary school level

\section{CONCLUSION}

By the results and findings of research, related to the formulation of the problem and research objectives, it can be concluded that the entrepreneurship-oriented projectbased student worksheet is feasible (valid, practical, and effective) to be used in learning to train students' collaboration and entrepreneurship skills. As life skills needed in $21^{\text {st }}$ century, collaboration and entrepreneurship, we hope that by this research students can master those skill and useful for their future. Meanwhile for the next research, we expect more variation for learning design to improve other important skills for the next centuries.

\section{ACKNOWLEDGMENT}

Naila, Jatmiko, and Sudibyo would like to thank all the party that help this research done. First goes to Rector of Muhammadiyah University Surabaya for the chance given to us for doing this research. Second goes to Headmaster of Muhammadiyah 4 Surabaya Elementary School and all teachers in 5th grade who help finish this research.

\section{REFERENCES}

[1] A. Calaprice, The ultimate quotable Einstein. Princeton University Press Princeton, NJ, 2011.

[2] Permendikbud no. 23 year 2016, "PERMENDIKBUD no.23 Tahun 2016," NO. 23

Tahun 2016, no. Standar Penilaian Pendidikan, 2016.

[3] P. E. Hunter and N. D. Botchwey, "Partnerships in Learning: A Collaborative Project between Higher Education Students and Elementary School Students," Innov. High. Educ., vol. 42, no. 1, pp. 77-90, 2017.

[4] L. R. Antil, J. R. Jenkins, S. K. Wayne, and P. F. Vadasy, "Cooperative learning: Prevalence, conceptualizations, and the relation between research and practice," Am. Educ. Res. J., vol. 35, no. 3, pp. 419-454, 1998.

[5] R. R. Hake, "Interactive-engagement versus traditional methods: A six-thousand-student survey of mechanics test data for introductory physics courses," Am. J. Phys., vol. 66, no. 1, pp. 64-74, 1998. 
[11] M. P. Trianto, "Mendesain Model Pembelajaran Inovatif-Progresif," Jakarta: Kencana, 2009.

environment to support Collaborative Project-Based Learning: A case study with the Group Investigation method," Turkish Online J. Distance Educ., vol. 18, no. 2, pp. 134-150, 2017.

[7] R. D. B. Rubrica, "An Action Research on ProjectBased Learning and Understanding by Design and Their Effects on the Science Achievement and Attitude of Science Students.," Online Submiss., 2018.

[8] M. Frank and A. Barzilai, "Integrating alternative assessment in a project-based learning course for preservice science and technology teachers," Assess. Eval. High. Educ., vol. 29, no. 1, pp. 41-61, 2004.

[9] K. Schwab, The fourth industrial revolution. Currency, 2017.

[10] A. Hassi, "Effectiveness of early entrepreneurship education at the primary school level: Evidence from a field research in Morocco," Citizenship, Soc. Econ.

Educ., vol. 15, no. 2, pp. 83-103, 2016.
[12] P. Sugiyono, "Metodologi penelitian kuantitatif kualitatif dan R\&D," Alpabeta, Bandung, 2011.

[13] I. Naila, B. Jatmiko, and E. Sudibyo, "Developing Entrepreneurship-oriented Project-based Learning Devices to Improve Elementary School Students ' Collaboration Skills .," Int. J. Innov. Sci. Res. Technol., vol. 4, no. 8, pp. 412-416, 2019.

[14] R. Trijono, "Metodologi penelitian kuantitatif," Jakarta: Papas Sinar Sinanti, 2015.

[15] P. L. Brown, J. P. Concannon, D. Marx, C. W. Donaldson, and A. Black, "An Examination of Middle School Students' STEM Self-Efficacy with Relation to Interest and Perceptions of STEM.," J. STEM Educ. Innov. Res., vol. 17, no. 3, 2016. 